\title{
СРАВНИТЕЛЬНАЯ ОЦЕНКА ЗАСУХОУСТОЙЧИВОСТИ МЕСТНЫХ СОРТОВ КУКУРУЗЫ
}

\author{
Бьлич Елена \\ Институт генетики, физиологии и защить растений, Кишинэу, Республика Молдова \\ e-mail: elena.balici@igfpp.md
}

\begin{abstract}
The paper presents the results of assessing local varieties of corn for drought tolerance. Samples of the collection were tested in the field in the agro-climatic conditions of 2020. The criterion of resistance was the genotypic differences of the samples of such biometric parameters as: plant height; the number of productive ears; ear weight; weight of 1000 grains. The influence of the limiting factor reduced the number of productive ears (on average for varieties to 0,48). A positive correlation of this indicator with the weight of the ear $(r=0,77)$ and the weight of 1000 grains $(r=0,43)$ was determined. Four varieties were identified that exceeded the standard in terms of the weight of the ear and four in terms of the weight of 1000 grains. As a result of a comparative analysis of yield parameters after exposure to drought, four local varieties were identified that can serve as donors of resistance genes.
\end{abstract}

Key words: drought tolerance, correlation, genotype.

\section{Введение}

Урожайность такой сельскохозяйственной культуры как кукуруза значительно снижается под влиянием периодически повторяющихся засух. Чтобы гарантировать сельское хозяйство от потерь в засушливые годы, необходимо иметь устойчивые к дефициту влаги сорта и гибриды. Эффективность и скорость селекции по этим направлениям зависят от количества информации, характеризующей генотипы и поступающей в каждом цикле исследований [3].

При создании засухоустойчивых гибридов кукурузы важно комплексное изучение селекционного материала. Выделение доноров и источников эффективной работы генетических систем, определяющих адаптивность и продуктивность родительских форм создаваемых гибридов [6,9].

Селекция на повышение адаптивного потенциала, является ведущим направлением исследований, оно было основой «народной селекции», при которой не ставилась задача получения рекордных урожаев, а ценилась устойчивость растений к неблагоприятным климатическим условиям и болезням. Создавать сорта с широким адаптивным потенциалом позволяло выращивание и отбор исходного материала в различных экологических нишах [4]. На сегодняшний момент старые местные сорта кукурузы не лишились своей значимости. Для сохранения и поддержания генетических резервов кукурузы в различных странах образованны национальные генбанки. Ведутся работы по сохранению, изучению и использованию этих сортов в селекции [7].

Целью исследований являлась полевая оценка местных стародавних сортов кукурузы на засухоустойчивость. По результатам ежегодных тестирований образцов кукурузы в экологических экспериментах, формируются специализированные коллекции.

\section{Материалы и методы}

Объектом исследований служили 24 среднепоздних местных сортов кукурузы (Молдавский желтый СР191, Молдавский желтый СР153, Молдавский желтый СР165, Оранжевая СР130, Молдавский желтый СР205, Молдавский желтый СР195, Семидентата СР122, Семидентата СР228, Семидентата СР174, Оранжевая СР196, Молдавский желтый СР185, Молдавский желтый СР137, Молдавский желтый СР128, Молдавский желтый СР115, Семидентата СР213, Семидентата СР149, Семидентата СР172, Молдавский желтый СР166, Семидентата СР122, Семидентата СР181, Молдавский желтый СР175, Молдавский белый СР152, Молдавский желтый СР132, Оранжевая СР 212 - стандарт), входящих в состав коллекции лаборатории Генетических ресурсов растений ИГФЗР.

Высеянные сорта изучали в поле, без полива, в агроклиматических условиях 2020 года. Использовали традиционную для данной культуры схему посева и агротехнику. Морфологические 
и биологические параметры определяли согласно классификатору для данной культуры [1]. Биометрические измерения включали определение высоты растений и числа продуктивных початков, веса початка, массы 1000 зерен, разрыв в цветении мужских и женских соцветий. Учеты и наблюдения проводились согласно методике полевых опытов с кукурузой [5].

Оценка образцов коллекции по засухоустойчивости была проведена в условиях, повышенного температурного режима и значительного дефицита влаги, которые отмечались на территории Молдовы в период июль-август 2020 года. Гидротермический коэффициент Селянинова (ГТК), характеризующий степень увлажнения территории, в среднем по республике в июле составил 0,5 , в августе - 0,2, что соответствует сильной и очень сильной засухе. По состоянию на 28 июля запасы продуктивной влаги под кукурузой в метровом слое почвы были низкими и составляли в основном 10-65 мм (15-60\% нормы) [8].

Полевые исследования проводились согласно рекомендациям [2], для обработки данных использовали компьютерный пакет программ Microsoft Office и др.

\section{Результаты и обсуждение}

Изучаемые сорта характеризовались существенными различиями по величине основных хозяйственно-ценных признаков в условиях дефицита влаги. Так, показатель высоты растений в среднем по сортам составил 160,8 см. Значительно ниже уровня стандарта этот показатель был у сорта Молдавский белый СР152, у остальных генотипов отличия от стандартного сорта были незначительны и соответствовали генотипическим особенностям роста (Рис.1).

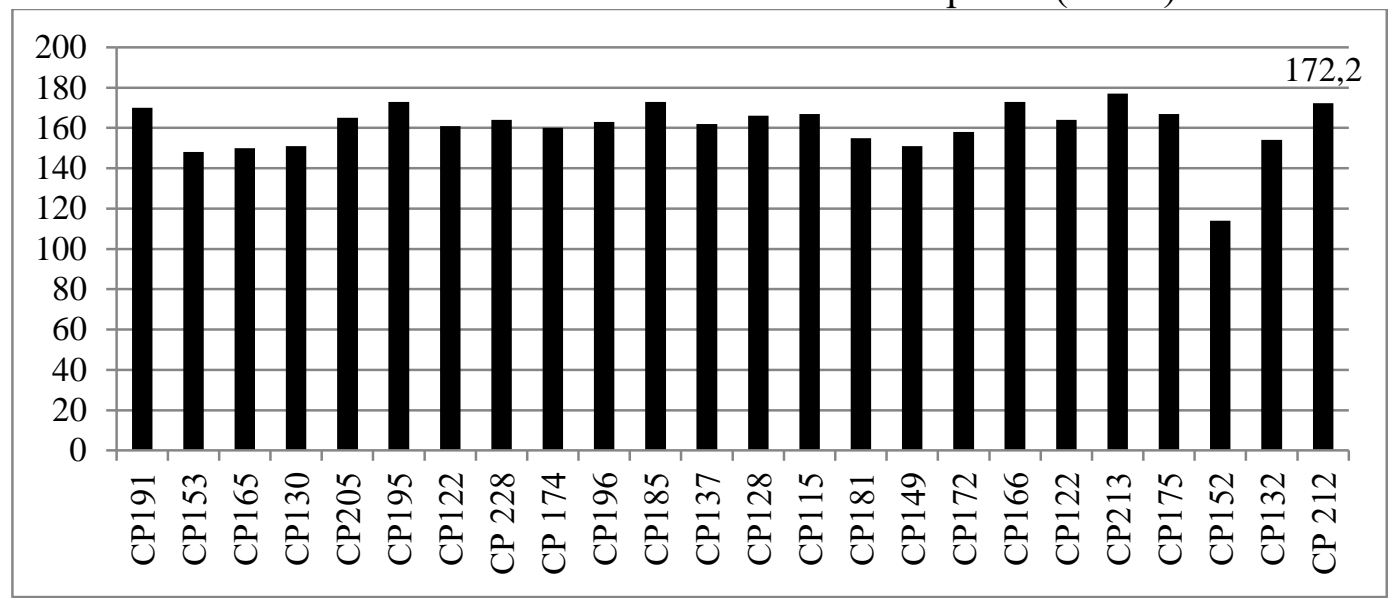

Рис.1 Высота растений среднепоздних сортов кукурузы, 2020 год.

Результаты фенологических наблюдений показали, что воздействие лимитирующего фактора повлияло, прежде всего, на прохождение растениями генеративной фазы, это привело к сокращению количества продуктивных початков (Рис.2). В среднем число растений, сформировавших початки составило по всем образцам 48\%, при минимальном его значении у сорта Молдавский белый СР152 (0\%). Повышенным уровнем в сравнении со стандартом (70\%), характеризовались сорта Молдавский желтый СР185, Молдавский желтый СР153, Оранжевая СР196, Молдавский желтый СР128 и Молдавский желтый СР175. Выявлена положительная корреляция этого параметра с высотой растений при $\mathrm{r}=0,38$.

В жару и засуху разрыв цветения мужских и женских соцветий у некоторых сортов существенно увеличивался, что негативно влияло на урожай. При оценке образцов коллекции по этому параметру, было выявлено 4 сорта (Семидентата СР122, Семидентата СР181, Молдавский желтый СР166, Молдавский белый СР152), у которых этот период превышал норму на 2, 3, 4, 5 дней (соответственно). 


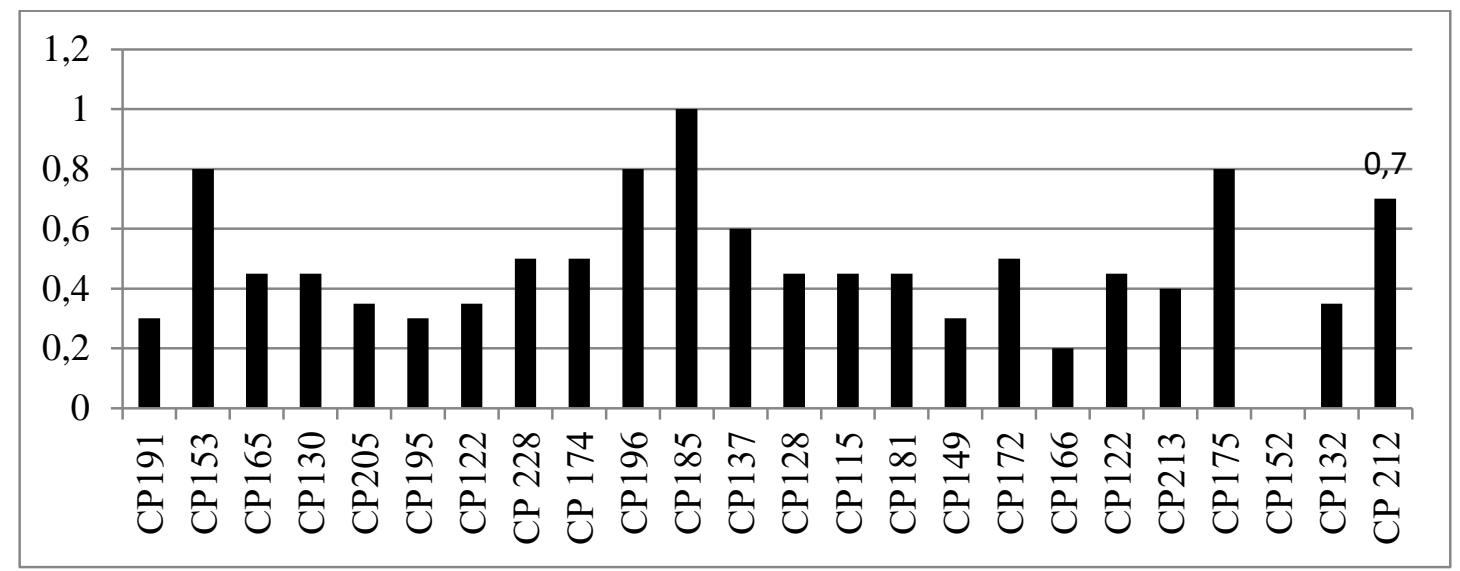

Рис.2 Количество продуктивных початков на растение у среднепоздних сортов кукурузы, 2020 год.

Статистический анализ данных по признаку “вес початка” выявил существенные различия по генотипам при среднем значении 19,8 г. В результате сравнительного анализа полученных данных, сорта были распределены на три группы по отношению к стандарту (Рис.3). В группу с показателями от 0 до 20 г вошли десять сортов. Вторую группу составили десять образцов с весом початка приближенному по значениям к стандартному сорту. Образцы коллекции Молдавский желтый СР185, Оранжевая СР196, Молдавский желтый СР175 и Молдавский желтый СР153, с более высокими показателями ( $\geq 27$ г), образовали группу устойчивых генотипов. При этом, была выявлена положительная корреляция веса початков с количеством сформированных початков $(\mathrm{r}=0,77)$.
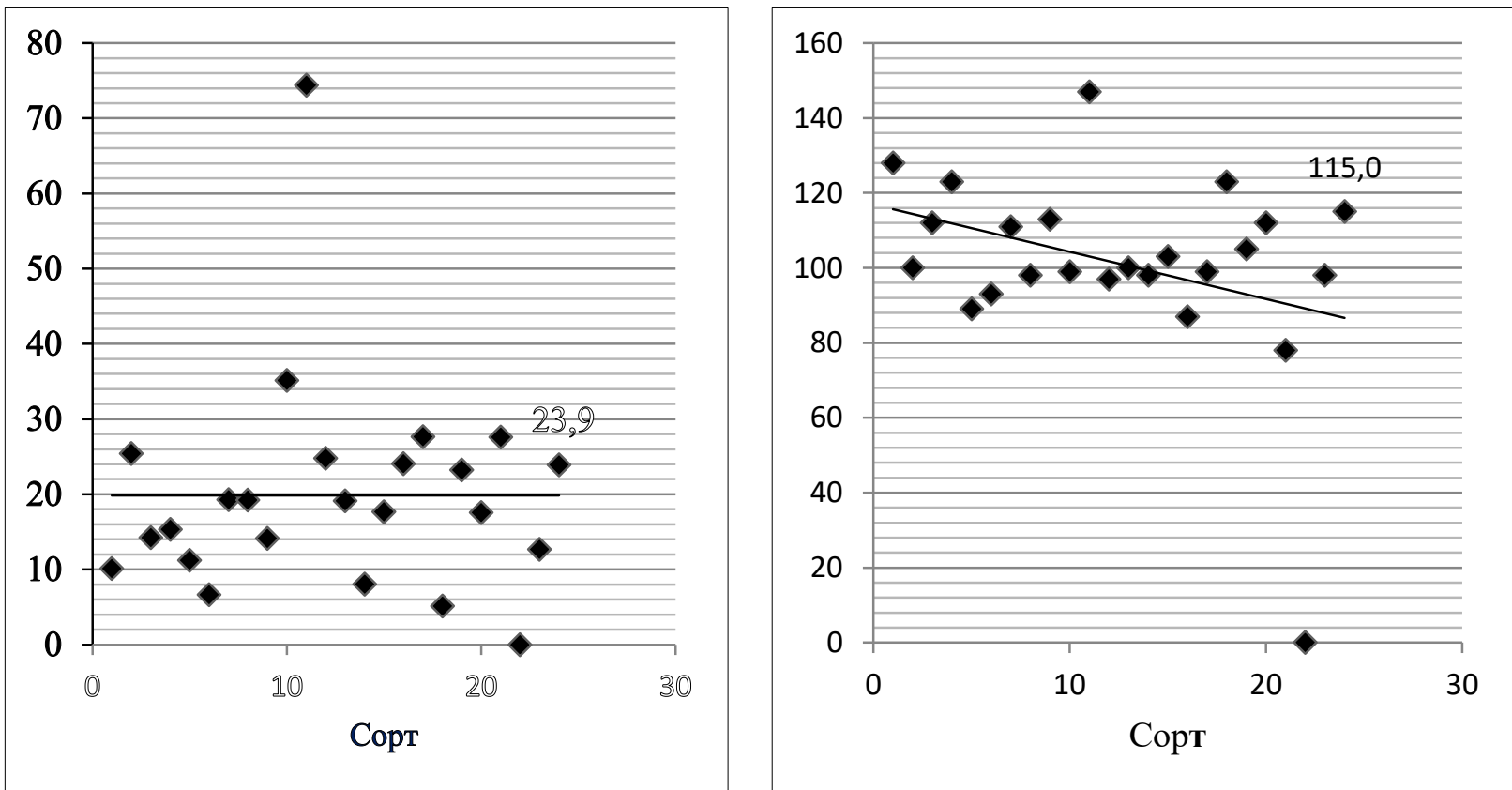

Рис.3, 4 Средние значения веса початка и массы 1000 семян (соответственно) по 24 сортам кукурузы, 2020 год.

Необходимо отметить, что показатель массы 1000 зерен (средние значения) варьировал от 0,0 до 123,0 г. (Рис.4). Статистическое распределение полученных данных определило три группы по отношению к стандартному образцу. С более низкими параметрами (от 0 до 90 г), в нее вошли одиннадцать сортов. С более высоким уровнем, чем у стандарта (от 120 г до143 г), выделены четыре сорта (Молдавский желтый СР185, Молдавский желтый СР191, Молдавский желтый СР166, Оранжевая СР130). Третью группу составили девять сортов с показателями, приближенными к уровню стандарта. Была определена сопряженность этого признака с количеством продуктивных початков $(\mathrm{r}=0,43)$ и весом початка $(\mathrm{r}=0,35)$. 


\section{Выводы}

Таким образом, в агроклиматических условиях 2020 года была проведена прямая оценка среднепоздних местных сортов кукурузы по толерантности к засухе. В результате исследований были выявлены генотипические различия по биометрическим показателям продуктивности растений.

Продолжительное воздействие лимитирующего фактора сократило число сформированных початков. В среднем по сортам, количество продуктивных растений, составило 0,48 \%. Выявлена положительная корреляция этого показателя с высотой растений $(\mathrm{r}=0,38)$, весом початков и массой 1000 зерен ( $\mathrm{r}=0,77$ и $\mathrm{r}=0,43$, соответственно).

В результате сравнительного анализа компонент продуктивности после воздействия стресса, были выделены четыре среднепоздних местных сорта кукурузы, которые могут служить донорами засухоустойчивости.

Исследования проведены в рамках проекта Государственной Программы 20.80009.5107.11 "Длительное сохранение генетических ресурсов растений в генном банке с использованием методов молекулярной биологии в тестировании состояния здоровья растительной зародышевой плазмы”, финансируемой Национальным Агентством по Исследованиям и Развитию.

1. Descriptors List species Zea mays L. 1986. Praha, 43 p.

\section{Литература}

2. ДОСПЕХОВ, Б.А. Методика полевого опыта. Москва, 1973. 335 с.

3. ЗЫКИН, В.А., МЕШКОВ, В.В., САПЕГА, В.А. Параметры экологической пластичности сельскохозяйственных растений, их расчет и анализ. Новосибирск, 1984.

4. КОРЗУН, О. С., БРУЙЛО, А. С. Адаптивные особенности селекции и семеноводства сельскохозяйственных растений. Гродно, 2011, 139 с.

5. Методические рекомендации по проведению опытов с кукурузой. // Днепропетровск: ВНИИ кукурузы, 1980, C. 36.

6. KUMAR, S. Targeting of traits through assessment of interrelationship and path analysis between yield and yield components for Grain Yield Improvement in single cross hybrids of maize / S. Kumar, M.T. Reddy, K.H. Reddy, P. Sudhakar, // International journal of applied biology and pharmaceutical technology, 3 (2), 2011 P.123-129.

7. PROSKOWETZ, E. von. Welches Werthverhältniss besteht zwischen/ Proskowetz E. von. // Intern. land und forstwirthschaftlicher Congress zu Wien 1890. Section I. Landwirthchaft. Subsection: Pflanzenbau, 1890, Frage 5, Heft 13.-S, P.3-18.

8. Serviciul Hidrometeorologic de Stat. Caracterizarea condiţiilor meteorologice şi agrometeorologice din anul 2020. Chişinău, 2020, http://www.meteo.md/ images/uploads/clima/2020.

9. ZHANG, J. Role of ABA in integrating plant responses to drought and salt stresses./ J. Zhang, W. Jia, J. Yang, A.M. Ismail // Field Crops Res.- 2006.-Vol.97, P 111-119. 